IRA-International Journal of Applied Sciences ISSN 2455-4499; Vol.04, Issue 01 (2016)

Institute of Research Advances

http://research-advances.org/index.php/IRAJAS

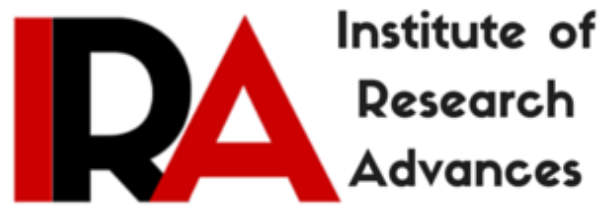

\title{
Screening of Upland Cotton Seed as a Nutrient Sources for Ruminants
}

\author{
${ }^{1}$ S. Mandhania, ${ }^{2}$ Rajvir Singh Sangwan, ${ }^{3}$ Omender Sangwan, ${ }^{4}$ Shiv Raj \\ Pundir \& ${ }^{5}$ Arun Janu \\ 1,2,3,4,5 Cotton Section, Department of Genetics and Plant Breeding, Chaudhary \\ Charan Singh Haryana Agricultural University-Hisar, India.
}

DOI: http://dx.doi.org/10.21013/jas.v4.n1.p20

How to cite this paper:

Mandhania, S., Sangwan, R., Sangwan, O., Pundir, S., \& Janu, A. (2016). Screening of Upland Cotton Seed as a Nutrient Sources for Ruminants. IRA-International Journal of Applied Sciences (ISSN 2455-4499), 4(1). doi:http://dx.doi.org/10.21013/jas.v4.n1.p20

(C) Institute of Research Advances

(c) EY-NC

This works is licensed under a Creative Commons Attribution-Non Commercial 4.0 International License subject to proper citation to the publication source of the work.

Disclaimer: The scholarly papers as reviewed and published by the Institute of Research Advances (IRA) are the views and opinions of their respective authors and are not the views or opinions of the IRA. The IRA disclaims of any harm or loss caused due to the published content to any party. 


\begin{abstract}
This study was designed to screen the thirty eight genotypes for their quality characteristics which can be exploited as feed for ruminant animals. The genotypes which posses high content of protein, oil and but low content of gossypol content will utilized for nutrient purpose. The protein and oil content were estimated by AOAC method, whereas, the gossypol content was estimated spectrophotomertically. The protein, oil and gossypol content ranged from 15.76 to 23.49, 11.37 to 16.23 and .011 to 0.29 percent respectively. The least gossypol content was observed in the ARBH $1501(0.11 \%)$ genotype but also has low quantity of protein (19.80\%) and oil (12.93\%). Genotypes $H$ 1478 and F2522 were best in terms of seed quality as seed of these genotypes contained more than $20 \%$ and $15 \%$ protein and oil content respectively, with less gossypol $(0.19 \%)$ content. Such genotypes can be exploited further as a good nutrient source for the ruminants.
\end{abstract}

Key words: Protein, Oil, Gossypol, Ruminants, Cotton seed.

\title{
INTRODUCTION
}

There is variability in the chemical composition and nutritional value of cottonseed and its byproducts (Cottonseed meal). Cottonseed and its byproducts (Cottonseed meal) are mostly used to feed adult ruminants, because off relatively tolerance to gossypol. It can be a good source of nutrient also for mono gastric provided that its limitations are taken into account, notably the fiber content and the presence of gossypol (Tanksley, 1990; Chiba, 2001). However, the utility of this nutrient source is hampered by the presence of toxic gossypol that is unique to the gossypieae. This cardio and hepatoxic terpenoid, present in all part of cotton plant, renders cotton seed unsafe for human mono gastric animal consumption (Risco and Chase, 1997). These compounds protect the plants from both insects and pathogens. After the discovery of a glandless mutant, several breeding programmes were launched in U.S. Africa and Asia to transfer the glandless trait into commercial varieties to produce gossypol free cotton seed. However, these glandless varieties were a commercial failure due to naturally un-competiveness. Many factors contribute to variation in the nutrient and gossypol content of cotton seed. Besides being the good source of protein and oil, it was not a good source of feed and food. However, these nutritional components are inter related and a variation in one may adversely affect the other like high protein cotton seed may have lower gossypol content (Mandhania et al., 2015). Thus keeping in mind the importance of nutritional composition of cotton seed, the present study was designed to screen the best genotypes in term of seed quality with higher amount of protein and oil but with less quantity of gossypol.

\section{MATERIALS AND METHODS}

Seeds of thirty eight G. hirsutum genotypes received from AICCIP trials, conducted during 2015-16 at Cotton Research Area, Cotton Section, Department of Genetics and Plant Breeding, CCS Haryana Agricultural University, Hisar, were used for this study. The seeds samples were oven dried to reduce the moisture level to meet the accuracy of the results. About $10 \mathrm{~g}$ whole cotton seed were ground to powder by using course grinding and then defatted for protein and gossypol analysis. Protein content was determined by Micro-kejdahl method of AOAC (1970). In this method the defatted samples were digested until solution becomes colorless. Further distillation and titration was done by using 40 per cent $\mathrm{NaOH}$ and $0.1 \mathrm{~N} \mathrm{HCl}$, respectively. The oil content was estimated by the method of AOAC (1970) using solvent extractor system. In this method, extraction of oil was done using non polar solvent petroleum benzene $\left(40-60{ }^{\circ} \mathrm{C}\right)$. The gossypol an anti nutrient component in cotton seed was estimated by using phloroglucinol reagent. The samples were taken in technical triplicate repeats for the respective constituents' analysis. The data was statistically analyzed by CRD design with the help of OPSTAT.

\section{RESULTS AND DISCUSSIONS}

The seeds of test genotypes were evaluated for protein, oil and gossypol content (Table 1). The highest protein content (23.49\%) was observed in H 1236 genotype. However, the genotypes F2532 and H 1478 were at par with the genotype H 1236. Zakirov et al., (1982) showed variation in 
crude protein content of cotton seed. Higher protein content was reported in the Nigerian commercial cotton seeds and Zhemian variety. The variation may be attributed to variety and location. The highest oil content (16.23\%) was observed in genotype PBH 21 and RS 2815 and genotypes RAH 1271 was found at par with entry PBH 21 for their oil content. The anti nutrient factor gossypol content was lowest in entry ARBH 1501. Whereas, highest was observed in entry BGDS 1055. The gossypol content present in genotypes H 1236, CSH 2920, TCH 1716 and BDGS 1066 were at par with highest gossypol containing entry BGDS 1055. Similar level of gossypol content in cotton seed was reported but low $(0.08 \%)$ gossypol content in cotton seed was observed by Renuka et al., (2005). Cotton seed meal (CSM) or meal contains gossypol (C30H30O8) which is toxic to farm animal.

Gossypol is produced in the pigment glands of the roots, leaves, stems, and seeds of the cotton plant genus Gossypium (Berardi and Goldblatt, 1969). Species and varieties of cotton plants differed in concentration of gossypol present in the seed. Pandey and Thejappa, (1975) reported variability in gossypol content with respect to the environment. The gossypol concentration is also influenced by method of oil extraction in cotton seed cake. Jones, (1981) reported that high temperature and pressure make cotton seed oil and meal less toxic as compared to solvent extraction method. Non-ruminants and pre-ruminants are more sensitive to gossypol toxicosis, but ruminant animals are somewhat resistant to toxicity. Reiser and $\mathrm{Fu}$, (1962) studied ruminants ability to detoxify free gossypol by binding with soluble proteins within the rumen and convert it into physiologically inactive form. Whereas, Smalley \& Bicknell, (1982) reported gossypol toxicosis in mature dairy cattle fed relatively high amounts of ammoniated whole cottonseed. (Grey et al., 1990) fed moderate amounts of cottonseed products containing free gossypol. Gossypol toxicity is also a potential problem when cotton products are fed to young calves with functionally undeveloped rumens (Leighton et al., 1953; Holmberg et al., 1988; Hudson et al., 1988; Kerr, 1989). The possible reduction of gossypol toxicity can be achieved by using iron salts. Iron salts bind gossypol in the gastrointestinal tract of swine and poultry fed CSM (Smith and Clawson, 1965), but this is not confirmed in ruminant animals.

Although gossypol problems are reported by various researchers, but in normal supplementary feeding, it is not a big problem.

\section{CONCLUSION}

The development of cotton genotypes which possess less amount of gossypol particularly in seed will be better option as a nutrient source for ruminants. In this content H 1478 and F 2522 were best in terms of seed quality as seed of these genotypes contained more than $20 \%$ and $15 \%$ protein and oil content respectively, with less than $0.2 \%$ gossypol content.

\section{REFERENCES}

AOAC. 1970. Official methods of analysis. Association of Official Analytical chemicals, edn Washignton DC, pp. 744-745.

Berardi, L.C. and Goldblatt, L.A. 1969. Gossypol. In: Toxic Constituents of Plant Foodstuffs. Liener, I.E., Academic Press Inc., New York, pp. 211.

Chiba, L. I. 2001. Proteins supplements. In: Swine nutrition, Lewis, A. J. and Southern, L. L., $2^{\text {nd }}$ Ed., CRC Press LLC, Boca Raton, London, New York,Washington, pp. 803-867.

Grey, M.L., Randel, R.D., Green, L.W. and Williams, G.L. 1990. Metabolic homeostasis and reproductive endocrine functions in postpubertal beef heifer fed varying levels of dietory free gossypol. J. Anim. Sci., 68 (supplement 1): 465.

Holmberg, C.A., Weaver, L.D., Guterbock, W.M, Genes, J. and Montgomery P. 1988. Pathologycal and toxicologycal studies of calves fed a high concentration cottonseed meal diet. Vet. Pathol., 25: $147-153$.

Hudson, L.M., Kerr, L.A. and Maslin, W.R. 1988. Gossypol toxicosis in a herd of beef calves. J. Am. Vet. Med. Assoc., 192(9): 1303-1305.

Jones, L.A. 1981. Nutritional values for cotton seed meal. Feed Stuffs, 53: 19-21. 
Kerr, L.A. 1989. Gossypol toxicosis in cattle. Comp. Cont. Ed., 11: 1139-1146.

Leighton, R.E., Anthony, W.B., Huff, J.S. and Rupel, I.W. 1953. Relation of dreed and free gossypol levels to cottonseed meal toxicity in dairy calves. J. Dairy Sci., 36: 601.

Mandhania, S., Pundir, S.R., Siwach, S.S., Sangwan, R.S., Sangwan, O., Nimbal, S. and Jain, A. 2015. Nutritional quality constituents' relationship in desi (Gossypium arboreum) cotton. $J$. Cotton Res. Dev., 29: 87-89.

Pandey, S.N. and Thejappa, N. 1975. Study on relationship between oil, protein, and gossypol in cottonseed kernels. J. Am. Oil Chem. Soc., 52: 312-315.

Reiser, R. and Fu, H.C. 1962. The mechanism of gossypol detoxification by ruminant animals. J. Nutr., 76: 215-218.

Renuka, C.K., Kumarmath, P.S., Kadakol, J.C. and Hosamani, S.V. 2005. Chemical composition and anti nutritional factors in different parts and whole cotton (G. hirsutum) plant. Karnataka J. Agric. Sci., 18: 114-117.

Risco, C.A. and Chase, C.C. J. 1997. In: Handbook of Plant and Fungal Toxicants, D’Mello, J.P.F., CRC Press, Boca Raton, FL, pp 87-98.

Smith, F.H. and Clawson, A.J. 1965. Effect of diet on accumulation of gossypol in the organs of swine. J. Nutr., 87: 317-321.

Smalley, S.A. and Bicknell, E.J. 1982. Gossypol toxicity in dairy cattle. Comp. Cont. Ed., 4: 378-381.

Tanksley Jr., T.D. 1990. Cottonseed meal. In: Non traditional feed sources for use in swine production, Thacker, P. A. and Kirkwood, R. N., Butterworth, Boston, pp. 139-151.

Zakirov, A., Nutritdinov, A.N. and Kiktev, M.M. 1982. Biochemical characaateristics of new cotton varieties in the collection. USSR Fanlar Akad. Dokl., 5: 57-58. 
Table 1: Seed protein, oil and gossypol content

\begin{tabular}{|c|c|c|c|}
\hline Genotypes & Protein (\%) & Oil (\%) & Gossypol (\%) \\
\hline ARBH-1501 & 19.80 & 12.93 & 0.11 \\
\hline TSH 321 & 22.49 & 12.50 & 0.18 \\
\hline CSH 2932 & 16.60 & 14.43 & 0.22 \\
\hline GSHV-173 & 19.29 & 11.37 & 0.26 \\
\hline RAH 1069 & 18.03 & 13.10 & 0.20 \\
\hline Local Check & 23.49 & 15.27 & 0.28 \\
\hline F 2522 & 22.07 & 15.13 & 0.17 \\
\hline ARBH-1502 & 16.27 & 13.00 & 0.20 \\
\hline HS 295 & 22.15 & 15.47 & 0.24 \\
\hline PBH 29 & 20.13 & 12.53 & 0.21 \\
\hline RB-602 & 19.63 & 13.47 & 0.17 \\
\hline CPD-1501 & 21.81 & 14.30 & 0.20 \\
\hline Zonal Check (H 1300/ CNHO 12/Suraj) & 20.47 & 13.50 & 0.22 \\
\hline SHM-55 & 22.23 & 14.23 & 0.24 \\
\hline CSH 2920 & 15.76 & 11.37 & 0.28 \\
\hline BGDS 1055 & 18.87 & 12.47 & 0.29 \\
\hline F 2532 & 22.65 & 15.37 & 0.25 \\
\hline CNH 126 & 20.89 & 13.83 & 0.22 \\
\hline H 1478 & 23.07 & 13.07 & 0.19 \\
\hline RS 2815 & 15.93 & 16.23 & 0.15 \\
\hline Quality Check (F 2164/Suraj/Suraj) & 20.47 & 13.73 & 0.20 \\
\hline RAH 1271 & 20.64 & 16.17 & 0.27 \\
\hline TCH 1716 & 22.23 & 15.43 & 0.28 \\
\hline $\mathrm{CCH} 15-1$ & 16.69 & 14.40 & 0.23 \\
\hline HS 296 & 18.96 & 14.23 & 0.22 \\
\hline GSHV-172 & 19.80 & 13.60 & 0.24 \\
\hline PBH 21 & 16.10 & 16.23 & 0.18 \\
\hline BGDS 1033 & 19.63 & 15.47 & 0.28 \\
\hline RS 2797 & 19.37 & 14.57 & 0.17 \\
\hline $\mathrm{CCH} 15-2$ & 17.53 & 12.77 & 0.19 \\
\hline CD at $5 \%$ & 1.17 & 0.46 & 0.01 \\
\hline SE(m) & 0.42 & 0.16 & 0.00 \\
\hline SE(d) & 0.59 & 0.23 & 0.01 \\
\hline $\mathbf{C V}$ & 4.20 & 2.00 & 3.39 \\
\hline
\end{tabular}

